\title{
PERBANDINGAN MODEL SIR (SUSCEPTIBLE, INFECTIOUS, RECOVERED), EXPONENTIAL MOVING AVERAGE DAN SINGLE EXPONENTIAL SMOOTHING PADA PERAMALAN COVID-19
}

\author{
Ade Bastian $^{1}$, Diana Surya Heriyana ${ }^{2}$, Sandi Fajar Rodiansyah ${ }^{3}$ \\ ${ }_{1,2,3}$ Program Studi Informatika, Fakultas Teknik, Universitas Majalengka \\ Email: 1adebastian@unma.ac.id, ${ }^{2}$ dsheriyana@gmail.com, ${ }^{3}$ galuh29@gmail.com
}

\begin{abstract}
ABSTRAK
Novel Coronavirus 2019 (COVID-19) is a disease caused by SARS-CoV-2, COVID-19 is a new type of coronavirus that can be transmitted from human to human. This virus can cause pneumonia, which is inflammation of the lung tissue that causes impaired oxygen exchange, resulting in shortness of breath. Currently it is not known when the Covid-19 pandemic will end, therefore a forecast is needed to predict the spread of Covid-19. This forecasting uses the SIR (Susceptible, Infectious, Recovered), Exponential Moving Average and Single Exponential Smoothing algorithm. Of the three algorithms, which data will be most suitable for forecasting the spread of covid-19 in Indonesia will be compared. The conclusion of the SIR model test results with the PSBB variable inhibits the spread of the virus, the exponential moving average test gets an error value of $24.28 \%$ and exponential smoothing gets an error value of $40.07 \%$. So the suitable algorithms used for covid-19 data are the sir model and the exponential moving average.
\end{abstract}

Kata Kunci: Forecasting, Covid-19, Model SIR, Exponential Moving Average, Single Exponential Smoothing

\section{PENDAHULUAN}

\subsection{Latar Belakang}

Novel Coronavirus 2019 (COVID-19) adalah penyakit menular yang disebabkan oleh SARS-CoV2, COVID-19 merupakan jenis virus baru coronavirus yang dapat menular dari manusia ke manusia. Virus ini dapat menyebabkan Pneumonia, yaitu peradangan pada jaringan paru yang menyebabkan gangguan pertukaran oksigen, akibatnya pernapasan menjadi sesak. Penderita COVID-19 dapat mengalami demam lebih dari 38 derajat celcius, batuk, sesak nafas yang membutuhkan perawatan di rumah sakit. (Fajar, 2020).

COVID-19 telah menyebar ke 196 Negara, sebanyak 8.692.305 kasus terkonfirmasi positif, 4.228.613 orang sembuh dan 458.706 orang meninggal dunia. Sementara itu, COVID-19 pertama kali terkonfirmasi di Indonesia pada tanggal 2 Maret 2020 sebanyak 2 orang dan per tanggal 20 Juni 2020 jumlah kasus terkonfirmasi positif sebanyak 43.803 orang, 17.349 orang sembuh dan 2.373 orang meninggal dunia. Terjadi kenaikan kasus terkonfirmasi positif setiap harinya hingga mencapai lebih dari 1.000 orang. (Kemenkes, 2020)

Di Indonesia telah diberlakukan Pembatasan Sosial Berskala Besar (PSBB) yang diterbitkan oleh Kementerian Kesehatan (Kemenkes) sebagai upaya untuk menghambat laju penyebaran COVID-19 dibeberapa wilayah zona merah. Pembatasan tersebut meliputi peliburan sekolah dan tempat kerja, pembatasan kegiatan keagamaan, pembatasan kegiatan di tempat atau fasilitas umum, pembatasan kegiatan sosial budaya, pembatasan moda transportasi dan pembatasan kegiatan lainnya khusus terkait aspek pertahanan dan keamanan.
Sesuai dengan data di atas, maka sangat diperlukan penyajian informasi berupa penerapan model penyebaran COVID-19 secara berkelanjutan kepada masyarakat. Penyebaran COVID-19 dapat dimodelkan ke dalam bentuk matematis. Model epidemik merupakan model yang bisa digunakan untuk meramalkan penyebaran virus ini. Model epidemik membagi populasi menjadi populasi Susceptible merupakan kelas populasi yang rentan terkena penyakit menular, Infected merupakan kelas populasi yang telah terinfeksi oleh suatu penyakit menular dan Recovered merupakan kelas populasi yang telah sehat atau sembuh setelah terinfeksi oleh penyakit. Model SIR adalah model epidemik yang paling umum digunakan dalam melihat persebaran penyakit. Model SIR yang diperkenalkan oleh Kermack dan McKendrick pada tahun 1927 dan pertama kali digunakan untuk melihat dinamika penyebaran populasi akibat penyakit menular. (Kasbawati, 2011)

Selain Model SIR, ada juga Model Exponential Moving Average untuk peramalan data deret waktu (time series). Model Moving Average digunakan jika data masa lalu merupakan data yang tidak memiliki unsur trend atau faktor musiman. Exponential Moving average forecasting banyak digunakan untuk menentukan trend dari suatu deret waktu. Tujuan utama dari penggunaan rata-rata bergerak adalah untuk menghilangkan atau mengurangi acakan (randomness) dalam deret waktu. Tujuan ini dapat dicapai dengan merata-ratakan beberapa nilai data bersama-sama, dengan cara mana kesalahankesalahan positif dan negatif yang mungkin terjadi dapat dikeluarkan atau dihilangkan. (Assauri, 1984) Model Single Exponential Smoothing juga bisa digunakan untuk peramalan data dari deret waktu (time series). Single Exponential Smoothing atau 
Penghalusan Exponensial merupakan prosedur perbaikan terus-menerus pada peramalan terhadap objek pengamatan terbaru. Metode peramalan ini menitik-beratkan pada penurunan prioritas secara eksponensial pada objek pengamatan yang lebih tua. Dalam pemulusan eksponensial atau single exponential smoothing terdapat satu atau lebih parameter pemulusan yang ditentukan secara eksplisit dan hasil ini menentukan bobot yang dikenakan pada nilai observasi. Dengan kata lain, observasi terbaru akan diberikan prioritas lebih tinggi bagi peramalan daripada observasi yang lebih lama. (Spyros Makridakis, 1999)

Seperti penelitian yang dilakukan oleh Ni Luh Ayu Kartika Yuniastari, dkk yang membandingkan algoritma Single dan Double Exponential Smoothing bertujuan untuk mengetahui algoritma yang cocok digunakan untuk penelitiannya. Berdasarkan hal tersebut, maka peneliti akan membandingkan tiga algoritma yaitu Model SIR, Exponential Moving Average dan Single Exponential Smoothing untuk memprediksi penyebaran virus COVID-19 dan dari ketiga algoritma tersebut nanti dapat diketahui mana yang lebih cocok digunakan untuk peramalan data COVID-19.

\subsection{Tinjuan Pustaka}

\section{a. Model SIR}

Model SIR adalah mode epidemic yang paling umum digunakan dalam melihat penyebaran penyakit. Model SIR yang diperkenalkan oleh Kermack dan McKendrick pada tahun 1927 dan pertama kali digunakan untuk dinamika penyebaran populasi akibat penyakit menular. (Fikri, 2020)

Alur penyebaran penyakit model SIR disajikan seperti berikut :

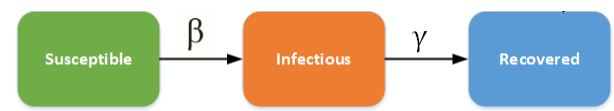

\section{Gambar 1. Alur Penyebaran Penyakit Model SIR}

\section{b. Moving Average}

Rata-rata bergerak (Moving Average) adalah suatu metode peramalan yang dilakukan dengan mengambil sekelompok nilai pengamatan, mencari nilai rata-rata tersebut sebagai ramalan untuk periode yang akan datang. Metode moving average digunakan jika data masa lalu merupakan data yang tidak memiliki unsur trend atau faktor musiman. Moving average forecasting banyak digunakan untuk menentukan trend dari suatu deret waktu. Tujuan utama dari penggunaan rata-rata bergerak adalah untuk menghilangkan atau mengurangi acakan (randomness) dalam deret waktu. Tujuan ini dapat dicapai dengan merata-ratakan beberapa nilai data bersama-sama, dengan cara mana kesalahankesalahan positif dan negatif yang mungkin terjadi dapat dikeluarkan atau dihilangkan. (Nurlifa, 2017)
Untuk mendapatkan nilai dari moving average sebelumnya ditentunkan terlebih dahulu jumlah periode (T). Setelah ditentukan jumlah periode yang akan digunakan dalam observasi pada setiap ratarata atau $\mathrm{MA}(\mathrm{T})$ dapat dihitung nilai rata-ratanya. Hasil dari nilai rata-rata bergerak tersebut kemudian akan menjadi ramalan untuk periode mendatang. Moving average tidak menggunakan data yang terdahulu terus-menerus, setiap ada data yang baru, data baru tersebut digunakan dan tidak lagi menggunakan nilai observasi yang paling lama, dikarenakan penggunaan jumlah periode selalu konstan.

\section{c. Exponential Smoothing}

Metode exponential smoothing adalah suatu prosedur yang mengulang perhitungan secara terus menerus yang menggunakan data terbaru. Setiap data diberi bobot, dimana bobot yang digunakan disimbolkan dengan $\alpha$. Simbol $\alpha$ bisa ditentukan secara bebas, yang mengurangi forecast error. Nilai konstanta pemulusan, $\alpha$, dapat dipilih diantara nilai 0 dan, karena berlaku: $0<\alpha<1$. (Yuniastari, 2014)

Alpha $(\alpha)$ merupakan parameter yang mengontrol pembobotan relative pada pengamatan yang baru dilakukan. Jika alpha bernilai 1 maka hanya pengamatan terbaru yang digunakan secara eksklusif. Sebaliknya bila alpha bernilai 0 maka pengamatan yang lalu dihitung dengan bobot sepadan dengan yang terbaru. Parameter alpha digunakan pada semua model.

\section{d. Forecasting}

Forecasting atau perkiraan adalah kegiatan yang bertujuan untuk meramalkan atau memprediksi segala hal yang terkait dengan produksi, penawaran, permintaan dan penggunaan teknologi dalam sebuah industri atau usaha. Perkiraan ini pada akhirnya akan digunakan oleh perusahaan maupun pihak manajemen operasional untuk membuat perencanaan terkait kegiatan usaha dalam beberapa periode tertentu.

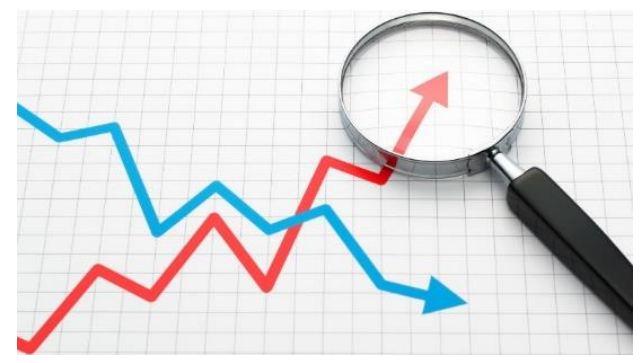

Gambar 2. Forecasting

Untuk menjamin sebuah tingkat perkiraan yang akurat dan bisa digunakan sebagai dasar perhitungan sebuah proses bisnis kedepannya, tentu butuh sebuah alat ukur yang akurat dan teruji berdasarkan jenis perkiraan itu sendiri. (Fothergill, 2016)

e. Time series

Data Time Series (Runtun waktu) merupakan jenis data yang dikumpulkan menurut urutan waktu dalam suatu rentang waktu tertentu. Jika waktu dipandang bersifat diskrit (waktu dapat dimodelkan 
bersifat kontinu), maka frekuensi pengumpulan datanya selalu sama (equidistant). Dalam kasus diskrit, frekuensi dapat berupa misalnya detik, menit, jam, hari, minggu, bulan atau tahun.

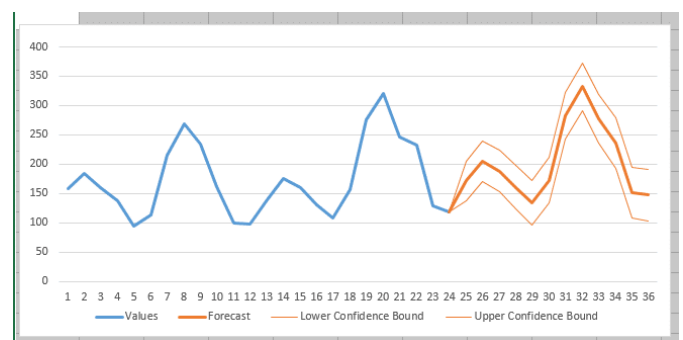

Gambar 3. Time Series Data

Salah satu contoh data time series adalah nilai indeks harga saham, yang dicatat dalam jangka waktu yang berurutan. Analisis data time series adalah analisa yang menerangkan dan mengukur berbagai perubahan atau perkembangan data selama satu periode. Analisis time series dilakukan untuk memperoleh pola data time series dengan menggunakan data masa lalu yang akan digunakan untuk meramalkan suatu nilai pada masa yang akan datang. (Ault, 2018)

\subsection{Metodologi Penelitian}

Kerangka penelitian Tugas Akhir tersebut terdiri dari beberapa tahapan yang dapat dijelaskan sebagai berikut :

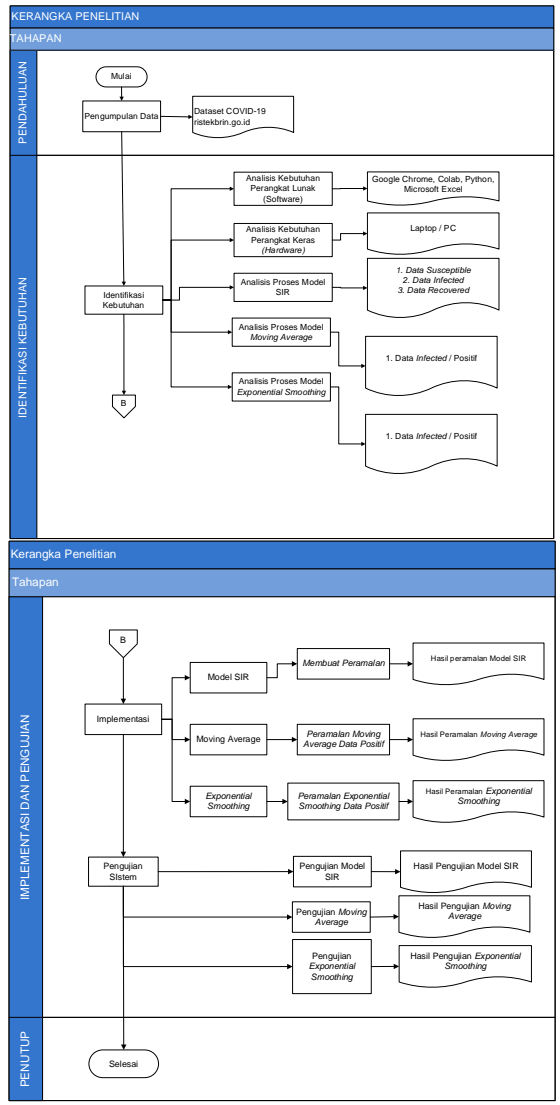

Gambar 4. Kerangka Penelitian
1) Pendahuluan

Tahap pendahuluan dimulai dari pengumpulan data untuk bahan proses peramalan. Dataset COVID-19 ini didapat dari Ristekdikti dengan halaman resmi: http://sinta.ristekbrin.go.id/covid/datasets. Ketika data sudah didapat maka akan dilakukan peramalan.

2) Identifikasi Kebutuhan

Tahap yang kedua yaitu identifikasi kebutuhan dimana pada tahapan ini merupakan bagian dari metode peramalan model SIR, Moving Average dan Exponential Smoothing. Dimana setiap model mempunyai kebutuhan data yang berbeda, kebutuhan perangkat keras (Hardware) dan kebutuhan perangkat lunak (software).

3) Implementasi

Tahap implementasi merupakan tahapan dilakukannya peramalan oleh tiga model algoritma yaitu Model SIR, Moving Average dan Exponential Smoothing. Sehingga nanti akan diperoleh hasil peramalan pada bulan berikutnya dan disajikan dalam bentuk grafik.

4) Pengujian

Tahap pengujian merupakan tahap yang dilakukan setelah melakukan peramalan. Dari ketiga algoritma tersebut diuji manakah algoritma yang cocok untuk peramalan covid-19. Pengujian berupa hasil persentase nilai peramalan dengan nilai actual.

5) Penutup

Tahap terakhir yaitu penutup, tahapan yang mendokumentasikan setiap hal yang dilakukan selama penelitian dan hasil yang telah didapatkan dalam bentuk laporan penelitian Tugas Akhir. Hal ini dilakukan agar hasil pada penelitian dapat dikembangkan pada penelitian selanjutnya.

\section{PEMBAHASAN}

Hasil yang diperoleh dalam penelitian ini adalah peramalan penyebaran COVID-19 menggunakan tiga algoritma yaitu Model SIR, Exponential Moving Average dan Single Exponential Smoothing. Dari hasil tersebut akan diketahui algoritma yang paling cocok digunakan untuk peramalan penyebaran COVID-19 dilihat dari persentase error nya. Berikut adalah data COVID-19 di Indonesia yang diambil dari RISTEK-BRIN (Kementerian Riset dan Teknologi - Badan Riset dan Inovasi Nasional Republik Indonesia) yang didownload dari http://sinta.ristekbrin.go.id/covid/datasets pada tanggal 1 Desember 2020 : 
Tabel 1. Dataset COVID-19

\begin{tabular}{|c|c|c|c|}
\hline Date & Positif & Sembuh & Meninggal \\
\hline $02 / 03 / 2020$ & 2 & 0 & 0 \\
\hline $03 / 03 / 2020$ & 0 & 0 & 0 \\
\hline $04 / 03 / 2020$ & 0 & 0 & 0 \\
\hline $05 / 03 / 2020$ & 0 & 0 & 0 \\
\hline$\ldots$ & $\ldots$ & $\ldots$ & $\ldots$ \\
\hline $26 / 11 / 2020$ & 4917 & 3842 & 127 \\
\hline $27 / 11 / 2020$ & 5828 & 3807 & 169 \\
\hline $28 / 11 / 2020$ & 5418 & 4527 & 125 \\
\hline $29 / 11 / 2020$ & 6267 & 3810 & 169 \\
\hline $30 / 11 / 2020$ & 4617 & 4725 & 130 \\
\hline
\end{tabular}

\section{a. Model SIR}

Penulisan matematis dari Model SIR $\frac{d S}{d t}=-\beta S$ I atau $S_{n}=S_{n-1}-\left(\left(\frac{S_{n-1}}{S}\right) *\right.$

$\left.\left(\beta * I_{n-1}\right)\right)$

$\frac{d I}{d t}=-\beta \mathrm{SI}-\gamma \mathrm{I}$ atau $I_{1}=I_{n-1}+\left(\frac{s_{n-1}}{s} *\right.$

$\left.\beta * I_{n-1}\right)-\left(I_{n-1} * \gamma\right)$

$\frac{d R}{d t}=\gamma \mathrm{I}$ atau $R_{1}=R_{n-1}+\left(I_{n-1} * \gamma\right)$

Model SIR dengan ditambahkan variable $\rho$ yang berarti menerapkan PSBB dapat dituliskan secara matematis sebagai berikut:

$$
\begin{aligned}
& S_{n}=S_{n-1}-\left(\left(\frac{s_{n-1}}{s}\right) *\left(\beta * \rho * I_{n-1}\right)\right) \\
& I_{1}=I_{n-1}+\left(\frac{s_{n-1}}{s} * \beta * I_{n-1} * \rho\right)- \\
& \left(I_{n-1} * \gamma\right) \\
& R_{1}=R_{n-1}+\left(I_{n-1} * \gamma\right)
\end{aligned}
$$

Diasumsikan Populasi $(\mathrm{N})=1.000 .000$

Orang terinfeksi Pertama $(\mathrm{IO})=2$

Orang sembuh Pertama $(\mathrm{R} 0)=0$

Variabel PSBB $(\rho)=0,5$

Orang yang rentan pertama $(\mathrm{S} 0)=\mathrm{N}-\mathrm{I} 0-\mathrm{R} 0=$ 999998

Banyaknya orang sembuh $=432868$

Banyaknya orang terinfeksi $=555045$
Laju penyebaran penyakit $(\beta)=1 / 5=0,2($ dimana 5 merupakan rentan waktu penyebaran virus)

Laju terinfeksi ke recovered $(\gamma)=$ Banyaknya orang sembuh / (banyaknya orang terinfeksi * rata-rata recover rate dalam sebulan) $=(\gamma)=$ $432868 /(555045 * 274)$

Tabel 2. Manual Forecasting SIR Model without PSBB

\begin{tabular}{|l|l|c|c|}
\hline Day & Susceptible & Infected & Recovered \\
\hline 1 & 999997,8 & 2,3943992 & 0,0056 \\
\hline 2 & 999997,121 & 2,86322239 & 0,0153754972 \\
\hline 3 & 999996,548 & 3,42584394 & 0,0237509944 \\
\hline 4 & 999995,863 & 4,09901991 & 0,0357414482 \\
\hline 5 & 999995,043 & 4,90447393 & 0,0500880179 \\
\hline
\end{tabular}

Tabel 3. Manual Forecasting SIR Model with PSBB

\begin{tabular}{|l|l|c|c|}
\hline Day & Susceptible & Infected & Recovered \\
\hline 1 & 999997,8 & 2,3943992 & 0.0056 \\
\hline 2 & 999997,581 & 2,40462358 & 0,0146754986 \\
\hline 3 & 999997,341 & 2,63666917 & 0,0230916811 \\
\hline 4 & 999996,814 & 3,15477326 & 0,0323200232 \\
\hline 5 & 999996,499 & 3,45920787 & 0,0433617296 \\
\hline
\end{tabular}

\section{b. Exponential Moving Average}

Persamaan matematis Exponential Moving Average adalah sebagai berikut:

$$
\mathrm{EMA}=\mathrm{Yt} * \mathrm{k}+\mathrm{EMA}(\mathrm{t}) *(1-
$$

$\mathrm{k})$

Keterangan:

Yt $=$ Nilai aktual ke $\mathrm{t}$

EMAt $=$ Nilai EMA periode $\mathrm{t}$

$\mathrm{k} \quad=2 / \mathrm{N}+1$

Tabel 4. Manual Forecasting Exponential

Moving Average

\begin{tabular}{|c|c|c|}
\hline Date & Positif & EMA \\
\hline $02 / 03 / 2020$ & 2 & 2 \\
\hline $03 / 03 / 2020$ & 0 & 1 \\
\hline $04 / 03 / 2020$ & 0 & 0,5 \\
\hline $05 / 03 / 2020$ & 0 & 0,25 \\
\hline $06 / 03 / 2020$ & 2 & 1,125 \\
\hline
\end{tabular}




\section{c. Single Exponential Smoothing}

Persamaan matematis Single Exponential Smoothing adalah sebagai berikut:

$$
\mathrm{St}=\alpha^{*} \mathrm{Xt}+(1-\mathrm{a}) * S_{t-1}
$$

Keterangan:

St $=$ Peramalan untuk periode $\mathrm{t}$

$\mathrm{Xt}+(1-\mathrm{a})=$ Nilai aktual time series

$S_{t-1}=$ Peramalan pada waktu $\mathrm{t}-1$ (waktu sebelumnya)

$\alpha \quad=$ Konstanta $(0<\alpha<1)$

Tabel 5. Manual Forecasting Single Exponential Smoothing

\begin{tabular}{|c|c|c|}
\hline Date & Positif & SES \\
\hline $02 / 03 / 2020$ & 2 & 2 \\
\hline $03 / 03 / 2020$ & 0 & 0,2 \\
\hline $04 / 03 / 2020$ & 0 & 0,02 \\
\hline $05 / 03 / 2020$ & 0 & 0,002 \\
\hline $06 / 03 / 2020$ & 2 & 1,8002 \\
\hline$\ldots$ & $\ldots$ & $\ldots$ \\
\hline $26 / 11 / 2020$ & 4917 & 4965,0 \\
\hline $27 / 11 / 2020$ & 5828 & 5741,0 \\
\hline $28 / 11 / 2020$ & 5418 & 5450,0 \\
\hline $29 / 11 / 2020$ & 6267 & 6185,0 \\
\hline $30 / 11 / 2020$ & 4617 & 4773,0 \\
\hline
\end{tabular}

\section{d. Pengujian Model SIR}

Model SIR (Susceptible, Infected, Recovered) tidak dapat dilakukan pengujian dengan MAPE, karena Model ini berbeda dengan Exponential Moving Average dan juga Single Exponential Smoothing. Model SIR ini merupakan model epidemic yang dkhususkan untuk penyebaran penyakit menular. Sehingga dari hasil peramalan yang telah dilakukan terdapat dua kondisi yaitu tidak adanya variable PSBB dan adanya variable PSBB. Dari kedua kondisi tersebut akan dibandingkan apakah penambahan variable PSBB dapat mengurangi atau menghambat laju penyebaran penyakit atau tidak. Berikut hasilnya:
Tanpa PSBB :

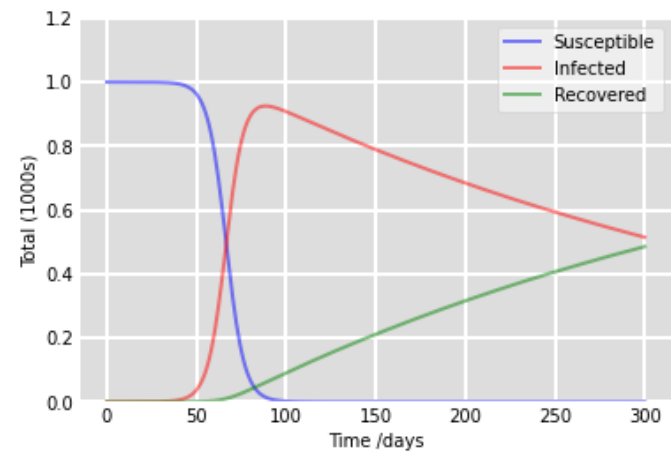

Gambar 5. Grafik Model SIR tanpa PSBB

Diterapkan PSBB:

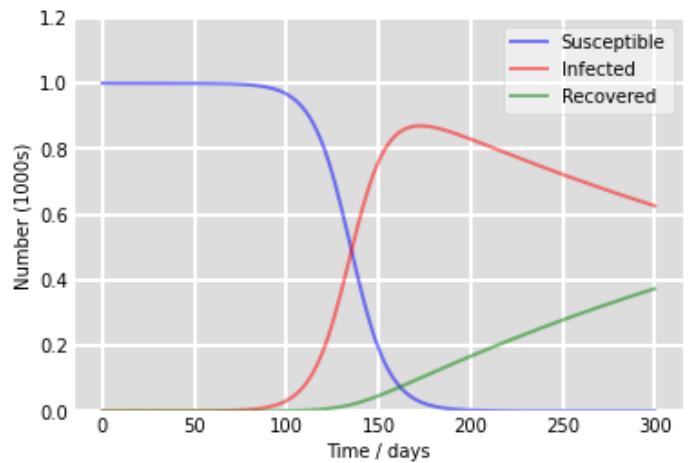

Gambar 6. Grafik Model SIR diterapkan PSBB

Grafik diatas menunjukan peramalan model SIR dengan waktu 300 hari dengan 3 kompartemen yaitu Susceptible (biru), Infected (merah) dan Recovered (hijau).

Ketika orang yang rentan (Susceptible) semakin menurun maka orang yang terinfeksi (Infected) semakin naik dikarenakan dari data yang dimasukan setiap harinya semakin banyak orang yang terkena infeksi. Kemudian orang yang terinfeksi menurun seiring dengan menaiknya laju penyembuhan (recovered).

Berbeda dengan grafik disebelah kanan yaitu diterapkannya PSBB, laju penyebaran penyakit semakin lambat dan berkurang dibandingkan dengan tanpa adanya variable PSBB. 


\section{e . Pengujian Exponential Moving Average}

Tabel 6. Testing Model Exponential Moving

Average

\begin{tabular}{|r|c|c|c|}
\hline Date & Positif & EMA & |P-EMA $/ \mathbf{P}$ \\
\hline $02 / 03 / 2020$ & 2 & 2.000000 & 0 \\
\hline $03 / 03 / 2020$ & 0 & 1.000000 & 0 \\
\hline $04 / 03 / 2020$ & 0 & 0.500000 & 0 \\
\hline $05 / 03 / 2020$ & 0 & 0.250000 & 0 \\
\hline $06 / 03 / 2020$ & 2 & 1.125000 & 0,4375 \\
\hline$\ldots$ & $\ldots$ & $\ldots$ & $\ldots$ \\
\hline $26 / 11 / 2020$ & 4917 & 4930.140204 & 0,002672403 \\
\hline $27 / 11 / 2020$ & 5828 & 5379.070102 & 0,077029838 \\
\hline $28 / 11 / 2020$ & 5418 & 5398.535051 & 0,003592645 \\
\hline $29 / 11 / 2020$ & 6267 & 5832.767526 & 0,069288731 \\
\hline $30 / 11 / 2020$ & 4617 & 5224.883763 & 0,131662067 \\
\hline & Total & & $\mathbf{2 1 , 4 3 4 4 9}$ \\
\hline
\end{tabular}

MAPE $=(21,43499 / 273) * 100=\mathbf{7 , 8 5 \%}$

Jadi, persentase error dari hasil peramalan Exponential Moving Average adalah $\mathbf{7 , 8 5 \%}$ yang berarti semakin kecil error maka semakin akurat datanya. Dengan hasil persentase error tersebut berarti nilai keakuratannya adalah $\mathbf{9 2 , 1 5 \%}$.

\section{f. Pengujian Single Exponential Smoothing}

Tabel 7. Testing Model Single Exponential

Smoothing

\begin{tabular}{|r|r|c|c|}
\hline Date & Positif & SES & $\mid$ P-SES $\mid / \mathbf{P}$ \\
\hline $02 / 03 / 2020$ & 2 & - & 0 \\
\hline $03 / 03 / 2020$ & 0 & 2.0 & 0 \\
\hline $04 / 03 / 2020$ & 0 & 0.0 & 0 \\
\hline $05 / 03 / 2020$ & 0 & 0.0 & 0 \\
\hline $06 / 03 / 2020$ & 2 & 0.0 & 0,0999 \\
\hline$\ldots$ & $\ldots$ & $\ldots$ & $\ldots$ \\
\hline
\end{tabular}

\begin{tabular}{|r|r|r|c|}
\hline Date & Positif & SES & $\mid$ P-SES $\mid / P$ \\
\hline $26 / 11 / 2020$ & 4917 & 5402.0 & 0,009869426 \\
\hline $27 / 11 / 2020$ & 5828 & 4966.0 & 0,014798765 \\
\hline $28 / 11 / 2020$ & 5418 & 5742.0 & 0,005975504 \\
\hline $29 / 11 / 2020$ & 6267 & 5450.0 & 0,013030552 \\
\hline $30 / 11 / 2020$ & 4617 & 6185.0 & 0,033968757 \\
\hline \multicolumn{5}{r|r|}{ Total } & $\mathbf{4 , 6 9 3 1 9 5 8 2 8}$ \\
\hline
\end{tabular}

MAPE $=(3,206 / 272) * 100=\mathbf{1 , 7 2 \%}$

Jadi, persentasi error dari hasil peramalan Moving Average adalah $\mathbf{1 , 7 2 \%}$ yang berarti semakin kecil error maka semakin akurat datanya. Dengan hasil persentase error tersebut berarti nilai keakuratannya adalah $\mathbf{9 8 , 2 8 \%}$.

\section{g. Pengujian Model SIR}

Model SIR (Susceptible, Infected, Recovered) tidak dapat dilakukan pengujian dengan MAPE, karena Model ini berbeda dengan Exponential Moving Average dan juga Single Exponential Smoothing. Model SIR ini merupakan model epidemic yang dkhususkan untuk penyebaran penyakit menular. Sehingga dari hasil peramalan yang telah dilakukan terdapat dua kondisi yaitu tidak adanya variable PSBB dan adanya variable PSBB. Dari kedua kondisi tersebut akan dibandingkan apakah penambahan variable PSBB dapat mengurangi atau menghambat laju penyebaran penyakit atau tidak. Berikut hasilnya:

\section{Tanpa PSBB:}

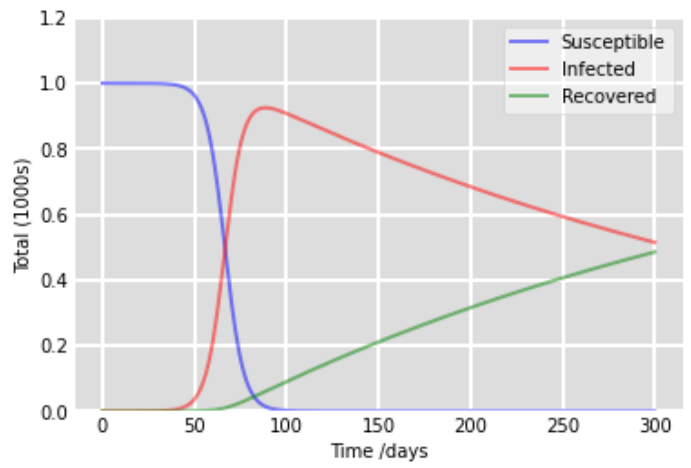

Gambar 7. Grafik Model SIR tanpa PSBB

Diterapkan PSBB: 


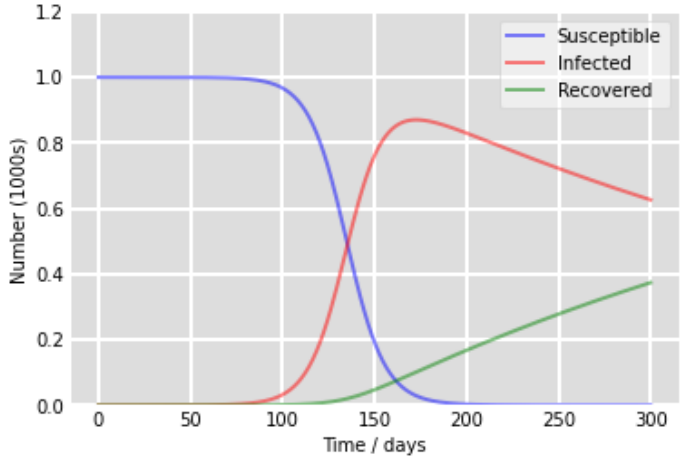

Gambar 8. Grafik Model SIR diterapkan PSBB

Grafik diatas menunjukan peramalan model SIR dengan waktu 300 hari dengan 3 kompartemen yaitu Susceptible (biru), Infected (merah) dan Recovered (hijau).

Ketika orang yang rentan (Susceptible) semakin menurun maka orang yang terinfeksi (Infected) semakin naik dikarenakan dari data yang dimasukan setiap harinya semakin banyak orang yang terkena infeksi. Kemudian orang yang terinfeksi menurun seiring dengan menaiknya laju penyembuhan (recovered).

Berbeda dengan grafik disebelah kanan yaitu diterapkannya PSBB, laju penyebaran penyakit semakin lambat dan berkurang dibandingkan dengan tanpa adanya variable PSBB.

\section{h. Pengujian Exponential Moving Average}

Tabel 8. Testing Model Exponential Moving

Average

\begin{tabular}{|r|c|c|c|}
\hline Date & Positif & EMA & $\mid$ P-EMA|/P \\
\hline $02 / 03 / 2020$ & 2 & 2.000000 & 0 \\
\hline $03 / 03 / 2020$ & 0 & 1.000000 & 0 \\
\hline $04 / 03 / 2020$ & 0 & 0.500000 & 0 \\
\hline $05 / 03 / 2020$ & 0 & 0.250000 & 0 \\
\hline $06 / 03 / 2020$ & 2 & 1.125000 & 0,4375 \\
\hline$\ldots$ & $\ldots$ & $\ldots$ & $\ldots$ \\
\hline $26 / 11 / 2020$ & 4917 & 4930.140204 & 0,002672403 \\
\hline $27 / 11 / 2020$ & 5828 & 5379.070102 & 0,077029838 \\
\hline $28 / 11 / 2020$ & 5418 & 5398.535051 & 0,003592645 \\
\hline $29 / 11 / 2020$ & 6267 & 5832.767526 & 0,069288731 \\
\hline $30 / 11 / 2020$ & 4617 & 5224.883763 & 0,131662067 \\
\hline
\end{tabular}

\begin{tabular}{|c|c|c|c|}
\hline Date & Positif & EMA & $\mid$ P-EMA $\mid /$ P \\
\hline \multicolumn{3}{|c|}{ Total } & 21,43449 \\
\hline
\end{tabular}

MAPE $=(21,43499 / 273) * 100=\mathbf{7 , 8 5 \%}$

Jadi, persentase error dari hasil peramalan Exponential Moving Average adalah $\mathbf{7 , 8 5 \%}$ yang berarti semakin kecil error maka semakin akurat datanya. Dengan hasil persentase error tersebut berarti nilai keakuratannya adalah $\mathbf{9 2 , 1 5 \%}$.

\section{i. Pengujian Single Exponential Smoothing}

Tabel 9. Testing Model Single Exponential

Smoothing

\begin{tabular}{|r|r|c|c|}
\hline Date & Positif & SES & $\mid$ P-SES|/P \\
\hline $02 / 03 / 2020$ & 2 & \multicolumn{1}{c|}{-} & 0 \\
\hline $03 / 03 / 2020$ & 0 & \multicolumn{1}{|c|}{2.0} & 0 \\
\hline $04 / 03 / 2020$ & 0 & 0.0 & 0 \\
\hline $05 / 03 / 2020$ & 0 & 0.0 & 0 \\
\hline $06 / 03 / 2020$ & 2 & 0.0 & 0,0999 \\
\hline$\ldots$ & $\ldots$ & $\ldots$ & $\ldots$ \\
\hline $26 / 11 / 2020$ & 4917 & 5402.0 & 0,009869426 \\
\hline $27 / 11 / 2020$ & 5828 & 4966.0 & 0,014798765 \\
\hline $28 / 11 / 2020$ & 5418 & 5742.0 & 0,005975504 \\
\hline $29 / 11 / 2020$ & 6267 & 5450.0 & 0,013030552 \\
\hline $30 / 11 / 2020$ & 4617 & 6185.0 & 0,033968757 \\
\hline & & Total & $\mathbf{4 , 6 9 3 1 9 5 8 2 8}$ \\
\hline
\end{tabular}

$$
\operatorname{MAPE}=(3,206 / 272) * 100=\mathbf{1 , 7 2 \%}
$$

Jadi, persentasi error dari hasil peramalan Moving Average adalah 1,72\% yang berarti semakin kecil error maka semakin akurat datanya. Dengan hasil persentase error tersebut berarti nilai keakuratannya adalah $\mathbf{9 8 , 2 8 \%}$

\section{KESIMPULAN}

Berdasarkan hasil pengujian algoritma Model SIR (Susceptible, Infected, Recovered), Exponential Moving Average dan Single Exponential Smoothing yang telah dilakukan peramalan, kesimpulan pada penelitian Tugas Akhir dengan judul "Perbandingan 
Model Sir (Susceptible, Infectious, Recovered), Exponential Moving Average dan Single Exponential Smoothing Pada Peramalan Penyebaran COVID-19 Di Indonesia" yaitu sebagai berikut:

1. Model SIR tidak dapat dilakukan pengujian menggunakan MAPE karena model ini merupakan model epidemic untuk meramalkan penyebaran penyakit menular sehingga proses peramalannya berbeda. Dan didapatkan hasil bahwa penambahan variable PSBB cukup efektif untuk menghambat laju penyebaran COVID-19.

2. Model Exponential Moving Average setelah dilakukan pengujian menggunakan MAPE (Mean Absolute Percentage Error) didapatkan hasil $7,85 \%$ atau keakuratannya sebesar $92,15 \%$.

3. Model Single Exponential Smoothing setelah dilakukan pengujian menggunakan MAPE (Mean Absolute Percentage Error) didapatkan hasil 1,72\% atau keakuratannya sebesar 98,28 $\%$.

Model yang cocok untuk peramalan data covid-19 ini adalah Model SIR dan Single Exponential Smoothing. Karena Model SIR dapat menyajikan pola penyebaran virus sedangkan Single Exponential Smoothing memperoleh tingkat keakuratan yang tinggi dibandingkan dengan Exponential Moving Average.

\section{PUSTAKA}

Ault, S. (2018, 06 01). Time Series Analysis and Forecasting Definition and Examples. Retrieved from Magosh Statistics Blog https://magoosh.com/statistics/time-seriesanalysis-and-forecasting-definition-andexamples/

Fajar, Muhammad. 2020. Estimation of COVID-19 Reproductive Number Case of Indonesian. Bandung : ResearchGate.

Fikri, R. 2020. SIR Model Pada Kasus COVID-19 Menggunakan Phyton. Bisa AI, 1.

Fothergill, D. 2016, 05 06). Three Golden Rules for Forecasting. Retrieved from Marketing Land : marketingland.com

Kasbawati. 2011. Analisis NUmerik Model Epidemiologi SIR dengan Faktor Difusi. Jurnal Matematika, Statistika dan Komputasi Vol. 7 No. 2 Januari 2011.

Kemenkes. 2020. Peta Sebaran COVID-19 di Indonesia. (Retrieved Juni 20, 2020, from Gugus Tugas Percepatan Penanganan COVID-19: www.covid19.go.id)

Nurlifa, A. 2017. Sistem Peramalan Jumlah Penjualan Menggunakan Metode Moving
Average Pada Rumah Jilbab Zaky. Jurnal Inovtek Polbeng Seri Informatika 1.

.Spyros Makridakis, S. C. 1999. Metode dan Aplikasi. Jakarta : Binarupa Aksara. 